Nowoczesne Systemy Zarządzania Zeszyt 14 (2019), nr 3 (lipiec-wrzesień) ISSN 1896-9380, s. 147-152

Modern Management Systems

Volume 14 (2019), No. 3 (July-September) ISSN 1896-9380, pp. 147-152
Instytut Organizacji i Zarządzania Wydział Bezpieczeństwa, Logistyki i Zarządzania

Wojskowa Akademia Techniczna w Warszawie

Institute of Organization and Management Faculty of Security, Logistics and Management Military University of Technology

Ku nowemu pragmatyzmowi: problemy i wyzwania wdrażania zrównoważonego rozwoju

\title{
Towards a new pragmatism: problems and challenges of implementing sustainable development
}

\author{
Jacek Woźniak \\ Wojskowa Akademia Techniczna \\ Wydział Bezpieczeństwa, Logistyki i Zarządzania
}

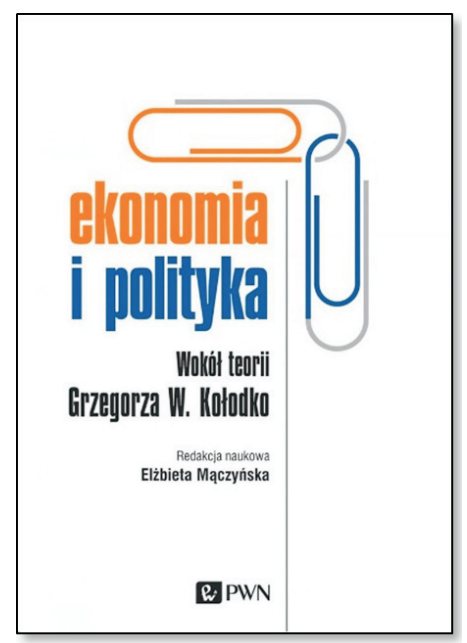

Recenzja książki pod redakcją naukową

Elżbiety Mączyńskiej

pt. Ekonomia i polityka. Wokół teorii Grzegorza W.

Kołodko,

Wydawnictwo Naukowe PWN, Warszawa 2019, ISBN: 978-83-01-20467-9, liczba stron: 472 
Współczesny świat dziwi i zaskakuje ludzi. Można nawet rzec, że im dłużej żyjemy, tym bardziej jesteśmy zdumieni tym, co widzimy, i tym, co musimy robić, aby utrzymać zachodzące procesy (zarówno w skali globalnej, jak i lokalnej) „,w ryzach” (Kuciński, 2011). Współczesny świat ewoluuje, zmierza w kierunku, którego my, ludzie, nie znamy, choć czasami wydaje się nam, że jest inaczej. Przyszłość zależy od nas - jest to wyzwanie, o którym trudno jest myśleć, bo wymaga dyscypliny intelektualnej i niezwykłej wrażliwości oraz spostrzegawczości (por. Szymański, 2007, 2011; Sedláček, Orrell, 2012; Mączyńska, 2014). Ważna jest również potrzeba i umiejętność zrozumienia przeszłości, teraźniejszości i przyszłości. Łatwo jest w tym względzie popełnić błąd, wysnuć błędne wnioski, zaproponować nieodpowiednie rekomendacje itp. (por. Galbraith, 2011; Chang, 2015; Sedláček, 2012). Dlatego mało kto podejmuje się tego szczególnego wyzwania, jakim jest holistyczna analiza świata i konstruktywna propozycja kierunków jego zmian (zob. Penn, Zalesne, 2009).

Jednym z badaczy, który nie boi się tak trudnego zadania jest profesor Grzegorz W. Kołodko, który od wielu lat systematycznie i z sukcesami rozwija koncepcję nowego pragmatyzmu (zob. Kołodko, 2008, 2010, 2013). Jest to propozycja o tyle szczególna i ważna, że integruje światy ekonomii, rozwoju społecznego oraz środowiska naturalnego. Swoistym spoiwem są procesy gospodarowania, stanowiące z jednej strony środek realizacji celów społeczeństwa, a z drugiej cel sam w sobie. Recenzowana książka stanowi wartościowe i spójne źródło analiz i rekomendacji odnośnie do tego, jak gospodarować, aby nie niszczyć tego, co nadejdzie - w myśl „ekonomii uczciwej”.

Recenzowana monografia poświęcona jest dorobkowi naukowemu profesora Grzegorza W. Kołodko i stanowi interesującą kompilację esejów oraz artykułów autorstwa uznanych naukowców i praktyków polityki gospodarczej, oscylujących wokół tez oraz koncepcji promowanych przez profesora G.W. Kołodko. Redakcji tego tomu podjęła się wybitna ekonomistka, prezes Polskiego Towarzystwa Ekonomicznego profesor Elżbieta Mączyńska, która w przedmowie zatytułowanej Ekonomia uczciwa zauważa, że „nie tylko badania naukowe, lecz nawet proste obserwacje rzeczywistości wskazują, że mimo niezaprzeczalnego, ciągłego materialnego i technologicznego postępu we współczesnym świecie coraz wyraźniejsze stają się przejawy występującego w skali globalnej nieładu, asymetrii oraz dysfunkcji w sferze gospodarczej, politycznej, społecznej i ekologicznej (...). Jednym z najbardziej spektakularnych tego przejawów są narastające nierówności dochodowe i rozległy zakres wykluczenia społecznego oraz utrzymujące się obszary głodu, dotykające około miliarda ludności świata, a także nasilające się przejawy aroganckiej rozrzutności i marnotrawstwa w świecie bogatych, świecie gospodarki nadmiaru" (Mączyńska, 2019, s. 9; zob. też Piketty, 2015). Rozwiązywanie tych problemów wymaga ciągłego, wręcz nieustannego zadawania pytań i podejmowania prób udzielania na nie odpowiedzi. Można przyjąć, że cała recenzowana książka jest zbiorem pytań i odpowiedzi - ale takich, które nie są ani oczywiste i tendencyjne, ani banalne. Jest to źródło wartościowej, 
bo użytecznej i inspirującej wiedzy. Profesor E. Mączyńska stwierdza, że „ekonomia, choć rozwijana od ponad 240 lat (licząc od 1776 r., tj. od czasu Adama Smitha), wciąż znajduje się - paradoksalnie - in statu nascendi: „Tak jak nie ma «końca historii», tak nie ma końca ekonomii. Tworzenie ekonomii jest pewnego rodzaju never ending story" (Mączyńska, 2019, s. 10). Wskazany proces dociekań nie ma końca i końca mieć nie może - a zatem obecnie generowane rozwiązania, wnioski i rekomendacje $\mathrm{w}$ niedługiej perspektywie będą musiały być poddane weryfikacji.

Rozważania zawarte w monografii (ujęte w 25 rozdziałach) zostały podzielone na cztery spójne tematycznie części: (1) Nowy pragmatyzm. Koncepcyjna oryginalność i praktyczna użyteczność, (2) Państwo i rynek, (3) Globalizacja i przyszłość, a także (4) Polskie wyzwania. Zatem Czytelnik jest „prowadzony” przez dorobek profesora G.W. Kołodko od perspektywy mikro-, przez perspektywy mezoi makroekonomiczną, aż do perspektywy megaekonomicznej. Cennym uzupełnieniem zawartości merytorycznej monografii jest odniesienie się do specyfiki polskiej gospodarki oraz wskazanie na uwarunkowania sprzyjające i niesprzyjające wdrażaniu i rozwijaniu założeń koncepcji nowego pragmatyzmu. Czytelnik ma również możliwość zaznajomić się z tzw. „ścieżką czasu G.W Kołodko”, czyli opisem etapów jego rozwoju zawodowego, a także wykazem jego wybranych publikacji. Wskazane powyżej aneksy pomagają Czytelnikowi lepiej zrozumieć koncepcję profesora G.W. Kołodko i jego sposób myślenia o rzeczywistości społeczno-ekonomicznej. Warto w tym miejscu podkreślić, że profesor G.W. Kołodko nie jest autorem żadnego z rozdziałów niniejszej monografii. Całość rozważań to refleksje innych badaczy i praktyków świata ekonomii, prawa i polityki (m.in. J. Wilkina, A.K. Koźmińskiego, E. Łętowskiej, M. Postuły, J. Kleera, W. Szymańskiego, W.M. Orłowskiego, M. Ratajczaka czy też B. Fiedora), co dodatkowo podkreśla wyjątkowość i niepowtarzalność merytoryczną całego tomu. Rzadko kiedy na polskim rynku wydawniczym pojawia się tak wnikliwa i jednocześnie wieloaspektowa oraz użyteczna praktycznie analiza procesów gospodarowania (od poziomu przedsiębiorstw do poziomu gospodarki narodowej i relacji ponadnarodowych, tj. międzynarodowych stosunków gospodarczych), będąca udaną próbą „stawienia czoła” kluczowym problemom współczesnego świata.

Przytoczone powyżej wprowadzenie autorstwa profesor E. Mączyńskiej stanowi swoiste „preludium” do kolejnych tekstów oraz jest to w pewnym stopniu „esencja” koncepcji nowego pragmatyzmu i w ogóle myśli profesora Grzegorza W. Kołodko. Niemniej jednak, jak wielokrotnie wyraźnie zaznaczają zarówno redaktorka tomu, jak i autorzy poszczególnych tekstów, książka nie ma na celu gloryfikowania koncepcji i osoby profesora G.W. Kołodko, tylko wskazanie obiektywnie silnych i słabych stron szerzonych przez niego teorii. Warto podkreślić, że niezwykle trudnym zadaniem jest obiektywne spojrzenie na tak bogaty i uznany na świecie dorobek wybitnego naukowca i uniknięcie popadnięcia w swoistą „przepaść pochlebstw”. Z całą pewnością można jednak zauważyć, że autorom i redaktorce recenzowanej książki to 
się udało. W wielu miejscach Czytelnik może zapoznać się nie tylko z opisem i afirmacją tez profesora G.W. Kołodko, lecz także z negacją niektórych elementów jego koncepcji. Stanowi to niezwykle wartościowy asumpt dla Czytelnika do własnych przemyśleń i krytycznej oceny rozwiązań pana profesora.

Czytelnik, po zapoznaniu się ze wstępem, ma świadomość tego, w jakim nurcie utrzymana będzie cała monografia. W części pierwszej pt. Nowy pragmatyzm. Koncepcyjna oryginalność i praktyczna użyteczność Czytelnik ma możliwość zaznajomienia się z fundamentami teoretycznymi koncepcji nowego pragmatyzmu. Ta część książki ma specyficzną formę, gdyż część tekstów stanowi swoiste porównanie nowego pragmatyzmu $\mathrm{z}$ innymi koncepcjami i nurtami w ekonomii, m.in. ordoliberalizmem i nowym nacjonalizmem. Co więcej, taki zabieg pozwala Czytelnikowi poznać i zrozumieć niuanse koncepcji profesora G.W. Kołodko i wskazać na jej wyjątkowość i poniekąd oryginalność. Na szczególną uwagę w tej części książki zasługuje tekst profesora S. Owsiaka na temat racjonalizacji wydatków publicznych oraz rozdział profesora $\mathrm{M}$. Goryni podający w wątpliwość poziom pragmatyzmu koncepcji nowego pragmatyzmu. Ostatni rozdział w tej części książki, autorstwa profesora S. Flejterskiego, na temat współczesnych finansów z perspektywy ekonomii umiaru oraz koncepcji nowego pragmatyzmu, stanowi logiczną i merytoryczną „podbudowę" dla drugiej części monografii, zatytułowanej Państwo i rynek. Dotyczy bowiem podstaw funkcjonowania określonych instytucji oraz rynków i ich powiązań z systemem zarządzania państwem.

W drugiej części omawianej książki nacisk został położony na problematykę uwarunkowań wdrażania i rozwijania kapitalizmu państwowego oraz na aspekty instytucjonalne i regulacyjne funkcjonowania państwa oraz gospodarki. Na uwagę zasługuje między innymi tekst profesora M. Bałtowskiego pt. Kapitalizm państwowy. Próba konceptualizacji, w którym zostały zaprezentowane podstawowe warunki, jakie muszą być spełnione, aby mógł zostać wdrożony kapitalizm państwowy, oraz wprost wyartykułowane są korzyści, a przede wszystkim zagrożenia wynikające $\mathrm{z}$ funkcjonowania tego systemu. Interesującym punktem odniesienia są $\mathrm{w}$ tym rozdziale uwarunkowania polskie oraz rozważania dotyczące zasadności i w ogóle możliwości wdrożenia w Polsce kapitalizmu państwowego. W tej części monografii wiele miejsca poświęcono także konieczności patrzenia na rozwój społeczno-polityczno-gospodarczy w sposób zrównoważony sensu largo, tj. nie tylko w kontekście propagowania sprawiedliwości, niwelowania nierówności społecznych, regulowania rynków finansowych i kształtowania dostępu do rzadkich zasobów w gospodarce, lecz także (jeśli nie przede wszystkim) ekologii/środowiska naturalnego.

Część trzecia książki pt. Globalizacja i przyszłość stanowi swoiste przejście na poziom megaekonomiczny, tj. funkcjonowania gospodarki krajowej w „sieci” globalnej. Poszukiwanie rozwiązań wielu społeczno-ekonomicznych problemów (w myśl koncepcji nowego pragmatyzmu) z perspektywy globalnej stanowi idealny punkt wyjścia do identyfikacji oraz konkretyzacji potencjalnych kierunków ewolucji 
procesów globalizacji (m.in. w kontekście geopolityki i geoekonomii). Część autorów stawia pytanie, w jakim kierunku i w jakim tempie będzie zmierzał świat i czy jest to kierunek przez nas wszystkich pożądany. Autorzy wskazują także na potencjalne zagrożenia, jakie mogą „czyhać” na ludzkość w jej szeroko pojętym rozwoju. W tym kontekście szczególnie interesujący wydaje się tekst profesora J. Kleera na temat przesileń cywilizacyjnych oraz rozważania profesora W. Szymańskiego w zakresie postępującego procesu autodestrukcji na świecie. Tym „silnym akcentem merytorycznym” i swoistym „wyzwaniem intelektualnym” kończy się część trzecia książki poświęcona problemom ogólnym, w pewnym sensie uniwersalnym w skali świata/różnych krajów.

Kolejne teksty, tworzące część czwartą (najkrótszą w całym tomie), dotyczą specyfiki Polski. W tym miejscu należy wyrazić smutek, że w zasadzie najważniejsza dla polskich Czytelników część książki jest najsłabiej rozwinięta - zbudowana jest zaledwie z czterech rozdziałów i w pewnym sensie pozostawia u Czytelnika niedosyt. Przecież osoba zainteresowana Polską i jej rozwojem - zwłaszcza w kontekście teorii promowanych przez profesora G.W. Kołodko - chciałaby poznać szersze spectrum przemyśleń i analiz na temat uwarunkowań rozwoju naszego kraju. Ponadto prezentowane $\mathrm{w}$ tej części tomu rozdziały są na różnym poziomie uszczegółowienia - od bardzo ogólnych do wąskich tematycznie zagadnień, a także dotyczą różnych problemów. W wyniku tego Czytelnik może odnosić wrażenie, że teksty nie do końca się uzupełniają. Niemniej jednak należy wyraźnie podkreślić, że poszczególne teksty odznaczają się szczególnie wysokim poziomem merytorycznym i są interesujące z poznawczego i utylitarnego punktu widzenia. Na uwagę zasługuje chociażby rozdział autorstwa profesora J. Kalińskiego dotyczący próby wprowadzenia w Polsce chinizmu czy też tekst autorstwa W.M. Orłowskiego dotykający szczególnie newralgicznego obecnie w polskim społeczeństwie i w elitach politycznych problemu zasadności i możliwości przyjęcia przez Polskę euro. Jest to też rozdział kończący „część merytoryczną” całego tomu.

Jak wcześniej wspomniano, książka jest zwieńczona aneksami poświęconymi osobie profesora Grzegorza W. Kołodko. Jest to szalenie interesujące dopełnienie treści merytorycznych. Niemniej jednak Czytelnik może odczuć swoisty brak zakończenia wszystkich rozważań, tj. podsumowania wspólnego dla ogółu problemów, przemyśleń, analiz i rozwiązań. Jest to o tyle odczuwalne, że zakres merytoryczny i złożoność problemów poruszanych w książce są duże. Podsumowanie mogłoby być użytecznym źródłem wskazówek dla Czytelnika i pomocą w praktycznym przełożeniu założeń koncepcji nowego pragmatyzmu na szeroko rozumiany zrównoważony rozwój społeczno-gospodarczo-środowiskowy państwa.

Konkludując, należy wyraźnie zaznaczyć, że recenzowana książka jest cennym źródłem wiedzy i powinna znaleźć się w kanonie lektur nie tylko naukowców i studentów z zakresu nauk społecznych, ale w zasadzie każdego Polaka. Monografia ta może bowiem kształtować fundamenty świadomości budowania zrównoważonego, racjonalnego i odpowiedzialnego państwa oraz społeczeństwa. 


\section{BIBLIOGRAFIA}

[1] Chang H.-J., 2015, Ekonomia. Instrukcja obsługi, Wydawnictwo Krytyki Politycznej, Warszawa.

[2] Galbraith J.K., 2011, Ekonomia w perspektywie. Krytyka historyczna, Polskie Towarzystwo Ekonomiczne, Warszawa.

[3] Коєорко G.W., 2008, Wędrujący świat, Prószyński i S-ka, Warszawa.

[4] Коєорко G.W., 2010, Świat na wyciagnięcie myśli, Prószyński i S-ka, Warszawa.

[5] Коєорко G.W., 2013, Dokąd zmierza świat. Ekonomia polityczna przyszłości, Prószyński i S-ka, Warszawa.

[6] Kucı́́sKi K. (red.), 2011, Glokalizacja, Wydawnictwo Difin, Warszawa.

[7] MĄCZYŃsKa E. (red.), 2014, Ekonomia dla przyszłości. Fundamentalne problemy teorii ekonomii i praktyki gospodarczej, Polskie Towarzystwo Ekonomiczne, Warszawa.

[8] Mączyńska E. (red.), 2019, Ekonomia i polityka. Wokół teorii Grzegorza W. Kołodko, Wydawnictwo Naukowe PWN, Warszawa.

[9] Penn M.J., Zalesne E.K., 2009, Mikrotrendy. Małe siły, które niosa wielkie zmiany, MT Biznes, Warszawa.

[10] Piketty T., 2015, Ekonomia nierówności, Wydawnictwo Krytyki Politycznej, Warszawa.

[11] SedláčEK T., 2012, Ekonomia dobra i zła, Wydawnictwo Studio Emka, Warszawa.

[12] Sedláček T., Orrell D., 2012, Zmierzch Homo Economicus, Wydawnictwo Studio Emka, Warszawa.

[13] Szymański W., 2007, Czy globalizacja musi być irracjonalna?, Oficyna Wydawnicza SGH, Warszawa.

[14] Szymański W., 2011, Niepewność i niestabilność gospodarcza: gwałtowny wzrost i co dalej?, Wydawnictwo Difin, Warszawa. 